\title{
都市の高温蒸気供給用ボイラ及び配管水溶液中の鉄系生成物
}

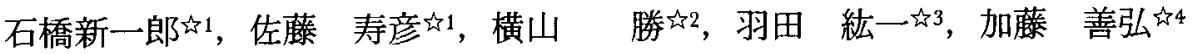

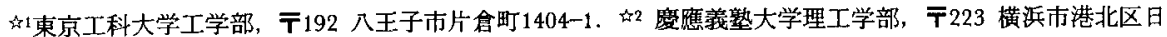

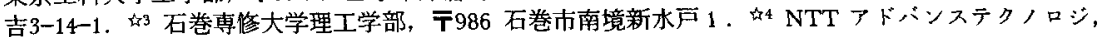 \\ テ243-01 厚木市森の里若宫3-1.
}

\section{Ferric Substance Formed in Circulateing Water for Boiler and Steam Piping Used for High Temperature Steam Supply Systems in City}

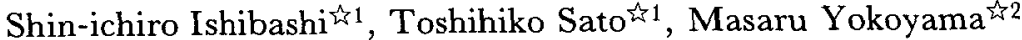

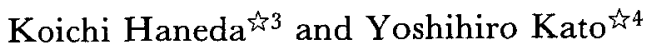 \\ \$1 Faculty of Engineering, Tokyo Engineering University, 1404-1 Katakura, Hachioji 192. th2 Faculty of Science \\ and Technology, Keio University, 3-14-1 Hiyoshi Kohoku-ku, Yokohama 223. s3 $^{3}$ School of Science and \\ Technology, Ishinomaki Senshu University, 1 Minamisakai Shinmito, Ishinomaki 986. 触 NTT Advanced \\ Technology, 3-1 Morinosato Wakamiya, Atsugi 243-01.
}

Received September 4, 1995

\section{SYNOPSIS}

Boilers are used to generate steam in many fields such as building and thermal power generation. Products from water evaporation adhere to boilers and their piping as scale or precipitate as sludge, obstructing the flow of steam to lower the thermal efficiency of steam. The detailed data on ferric substance in compositions of such scale and sludge are not well known yet. The author have reported about detailed results of studies emphasizing ferric substance in boilers and their piping used for heating building with steam of $100^{\circ} \mathrm{C}$. To clarify the compositions of such substance, we have studied boilers that supply high temperature steam of $180^{\circ} \mathrm{C}$ to high-rise buildings, mainly investigating the ferric substance in boilers and piping. What has attracted our attention in the study is the fact that ferromagnetic magnetite $\left(\mathrm{Fe}_{3} \mathrm{O}_{4}\right)$ and weakmagnetic hematite $\left(\alpha-\mathrm{Fe}_{2} \mathrm{O}_{3}\right)$ accounted for about $98 \%$ of the substances. The average grain sizes of magnetite and hematite were about $105 \mathrm{~nm}$ and $160 \mathrm{~nm}$ respectively, being larger than those of the heating boilers due to the higher steam temperature. The saturation magnetization was about $79 \mathrm{emu} / \mathrm{g}$, and $82 \mathrm{emu} / \mathrm{g}$ when corrected for nonmagnetic layer, being close to the bulk magnetite.

\section{KEY WORDS}

ferric substance, magnetite $\left(\mathrm{Fe}_{3} \mathrm{O}_{4}\right)$, hematite $\left(\alpha-\mathrm{Fe}_{2} \mathrm{O}_{3}\right)$, boiler, high temperature steam.

\section{1 緒 言}

蒸気発生装置としてのボイラは，ビルの暖房から 火力発電所に至るまで，多方面に利用されている。 ビル暖房の場合，ボイラから発生する蒸気源は，主 として市水の水道水が利用されている，しかし，多 少の美はあるが、市水には常に $\mathrm{Ca} 、 \mathrm{Mg} 、 \mathrm{Si}$ 等がイオ ンの形で溶け込んでいて, $\mathrm{CaCO}_{3}, \mathrm{MgCO}_{3}, \mathrm{SiO}_{2}$ 等の化 合物として析出し、ボイラ及び配管内にスケールと して付着したり，スラッジとして沏殿して水蒸気の 流れを阻害し，蒸気の熱效率低下の原因になってい
る、これらボイラ及び配管内で生成するスケール等 の成分については，従来から検討されてきたが、11 31 この中で鉄系生成物の詳細なデータはあまり知られ ていないようである，そこで筆者等は，先に蒸気発 生温度が $100^{\circ} \mathrm{C}$ のビル等の暖房に使用されるボイラ及 び配管水溶液中で生成されるスケールとスラッジに ついて詳細な成分分析を行うとともに，特に鉄系生 成物に重点を置いた詳綀な検討結果を報告した。)今 回の研究は蒸気発生温度が $180^{\circ} \mathrm{C}$ の高温蒸気を都市の 高層ビル等へ供給するボイラについて，鉄系生成物 
に重点をおいて研究を行った，以下にこれらの検 討結果について報告する.

\section{2 実験方法}

研究対象としたボイラは，都市の高層ビル等への 高温蒸気供給用のもので，ボイラ及び熱交換機等の 配置を Fig. 1 に示す．これらボイラ，配管及び熱交 換機等は鉄製であるが，熱交換機内のパイプは銅製 である. ボイラの蒸発源となるイオン交換水の $\mathrm{pH}$ は， 稼佺時から $\mathrm{NaOH}$ 等により10.5〜11.0に維持されてい る. ボイラ、配管水溶液及びフィルタからの生成物

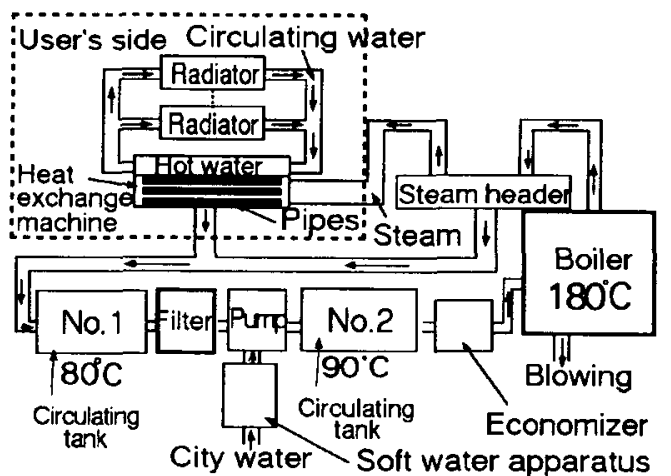

Fig.l Arangement of boiler and piping facility.

は淡黄色をしており，これを永久磁石（バリウムフ ×ライト磁石使用，磁束密度500ガウス)により，ま ず乾式で磁気分離（粗選）を行い，次いで粗選で得た 各磁着物をエタノール中で靦拌しながら，湿式で磁 気分離 (精選)を行った，精選された磁着物は灰褐色 で、強い磁性を示した。ボイラ等から採集した状態 のものを生成物，それらを磁気分離したものを磁着 物及び非啹着物と呼んで以下に実験結果を示した。

ボイラ、配管水溶液及びフィルタからの生成物中 の各成分元素の含有量は，蛍光 X 線定性分析装置に より測定した。 また，X線回折により，生成物，磁着 物. 非磁着物についての含有物質の同定を行った。 さらに，強磁性物質，弱磁性物質についてそれぞれ 格子定数を求めるとともに，平均結晶子の大きさを Scherrer の式により算出した．磁着物の粒子形態， 粒度等については透過型電子顕微鏡 (TEM)による锶 察を、それらの超微小領域の組成分析をエネルギー 分散型 X 線マイクロ分析 (EDX) によって行った. 生 成物，磁着物及び非磁着物それぞれの的和磁化 $\mathrm{s}_{\mathrm{s}}$ 及 び保磁力 $\mathrm{H}_{\mathrm{c}}$ は振動試料型磁力計 (VSM) により $300 \mathrm{~K} て ゙$ $15 \mathrm{k} 0 \mathrm{e}$ の外部磁界を与えて湘定した。

\section{$3 \cdot 1$ 生成物の諸性質}

\section{3 実験結果及び考察}

\section{$3 \cdot 1 \cdot 1$ 蛍光 X 線定性分析}

蛍光 X 線定性分析結果を Table 1 に示した. 同表の 分析結果は，存在の可能性が考えれる化合物，すな わち酸化物，炭酸塩等を化学式で示し，全量を $100 \%$ としたものである，高温蒸気用ボイラではイオン交 換水を使用しているので， $\mathrm{CaCO}_{3} 、 \mathrm{MgCO}_{3}$ 等はほとんど 含まれていない，生成物中には鉄酸化物が約 $98 \%$ む 含まれており，また， $\mathrm{Si}_{2} ， \mathrm{Cu} 0$ 等もそれぞれ約 $1 \%$ 程含まれている，一力，フィル夕からの生成物中に 屯鉄酸化物は約 $88 \%$ と多く含まれており，注目され ることは Cu0 が約 10\%も含まれている点である.こ れは蒸気を供給している高層ビル等の中に熱交換機 が設置されており，この機内のパイプから，銅が少 しずつ溶出し、フィルタで採集されたためと考えら れる.この他に少量の $\mathrm{SiO}_{2} や \mathrm{ZnO}$ む含まれている。

Table 1 Flourescent $X$-ray spectrographic analysis of substance formed in boilers.

\begin{tabular}{|c|c|c|c|c|c|c|}
\hline & \multicolumn{3}{|c|}{ Boller } & \multicolumn{3}{|c|}{ Filter } \\
\hline & & 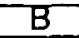 & & $\bar{A}$ & D & $C$ \\
\hline $\mathrm{CaCO}_{3}$ & 0.04 & 0.00 & 0.00 & 0.20 & 0.20 & 0.20 \\
\hline $\mathrm{MgCO}_{3}$ & 0.00 & 0.00 & 0.00 & 0.00 & 0.00 & 0.00 \\
\hline $\mathrm{Fe}_{2} \mathrm{O}_{3}+\mathrm{Fe}_{3} \mathrm{O}_{4}$ & 98 & 99 & 98 & 88 & 89 & . \\
\hline CuO & 0.50 & 0.40 & 0.60 & 9.40 & 8.30 & 1.0 \\
\hline ZnO & 0.00 & 0.00 & 0.00 & 1.00 & 1.00 & 1.00 \\
\hline $\mathrm{STO}_{2}$ & 0.60 & 0.50 & 0.40 & 0.60 & 0.60 & 0.70 \\
\hline $\mathrm{A}_{2} \mathrm{O}_{3}$ & 0.04 & 0.02 & 0.03 & 0.09 & 0.09 & 0.10 \\
\hline MnO & 0.08 & 0.06 & 0.04 & 0.07 & 0.08 & 0.01 \\
\hline $\mathrm{O}_{3}$ & 0.20 & 0.10 & 0.20 & 0.30 & 0.20 & 0.30 \\
\hline
\end{tabular}

A:Substance B.Magnetic Substance

C:Non-magnet ic substance

$3 \cdot 1 \cdot 2 X$ 線回折

Fig. 2 と3はボイラ及びフィルタから得た生成物。 距着物，及び非磁着物についてX線回折による同定 結果である. 生成物ではスピネル (spinel) 結晶構造 の物質と六方晶の物質の回折線がみられる。磁着物 では、スピネル結晶構造物質による強度比が最も大 きくなっている．非磁着物では殆どが六方晶の物質 である.これらの物質の格子定数を Table2に示した． スピネル結晶物質は $\mathrm{Fe}_{3} \mathrm{O}_{4}$ と考えられ，六方晶の物質 は $\alpha-\mathrm{Fe}_{2} \mathrm{O}_{3}$ である. Fig. 2 及び 3 の回折線で，生成物 の $\mathrm{Fe}_{3} \mathrm{O}_{1}$ の最強線に $\alpha-\mathrm{Fe}_{2} \mathrm{O}_{3}$ が重なっており，そのた め強度比の割合がわかりにくくなっている，先に報 告したように。" 蒸気発生温度が 100 Cの暖房用ボイ ラで生成される鉄系生成物の場合には，強磁性物質 である $\mathrm{Fe}_{3} \mathrm{O}_{4}\left(\gamma-\mathrm{Fe}_{2} \mathrm{O}_{3}\right.$ 化された $\mathrm{Fe}_{3} \mathrm{O}_{4}$ も含む) が主であ ったが、蒸気発生温度が $180^{\circ} \mathrm{C}$ 高温蒸気供給用ボイ ラの場合には，鉄系生成物の中で， $\mathrm{Fe}_{3} \mathrm{O}_{4}$ に加えて， 
弱磁性物質の $\alpha-\mathrm{Fe}_{2} \mathrm{O}_{3}$ が含まれていることが分かった なお，蛍光 X 線定性分析でCuが $10 \%$ 近く含有されて

Table 2 Lattice constant and average crystallite size of magnetic substance.

\begin{tabular}{|c|c|c|c|c|c|}
\hline & \multicolumn{2}{|r|}{$\mathrm{Fe}_{3} \mathrm{O}_{4}$} & \multicolumn{3}{|c|}{$\alpha-\mathrm{Fe}_{2} \mathrm{O}_{3}$} \\
\hline & $\begin{array}{l}\text { Lattice } \\
\text { constant }\end{array}$ & $\begin{array}{c}\text { Crystallite } \\
\text { size }\end{array}$ & $\begin{array}{l}\text { Latt } \\
\text { cons }\end{array}$ & $\begin{array}{l}\text { ice } \\
\operatorname{tant}\end{array}$ & $\begin{array}{c}\text { Crystallite } \\
\text { size }\end{array}$ \\
\hline & $a(\mathrm{~nm})$ & $D(\mathrm{~nm})$ & $*_{a}(\mathrm{~nm})$ & ${ }^{*} \mathrm{c}(\mathrm{nm})$ & ${ }^{*} D(\mathrm{~nm})$ \\
\hline Boiler & 0.839 & 105 & 0.503 & 1.38 & 161 \\
\hline Filter & 0.835 & 27 & 0.502 & 1.37 & 24 \\
\hline
\end{tabular}

$* \alpha-\mathrm{F} \mathrm{e}_{2} \mathrm{O}_{3}$ (bulk) a:0.503, c: 1.37(nm)

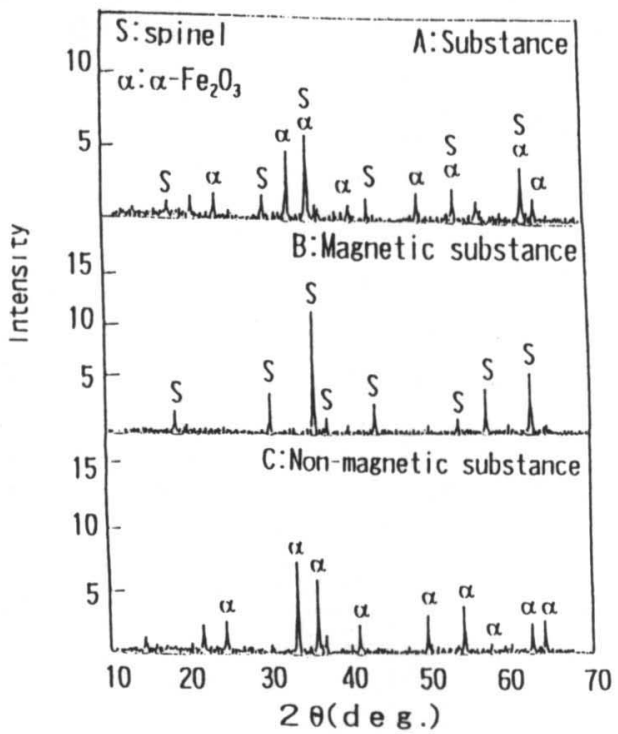

Fig.2 X-ray diffraction patterns of the substances formed in boiler.

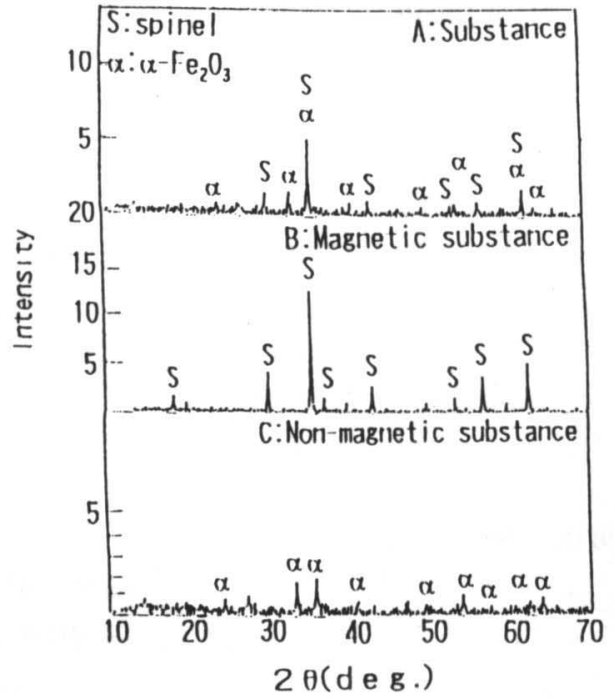

Fig. $3 X$-ray diffraction patterns of the substances formed in filter.
いるフィルタについては，Fig. 3 において，Cu0によ る回折線はみられず， $\mathrm{Cu} 0$ 成分は $\mathrm{Fe}_{3} \mathrm{O}_{4}$ に固溶してい る可能性がある.

$\mathrm{Fe}_{3} \mathrm{O}_{4}$ の格子定数はボイラの場合，バルクのそれと 一致している.フィルタの場合は，やや小さく， $\gamma$ $\mathrm{Fe}_{2} \mathrm{O}_{3}$ 化した $\left.\mathrm{Fe}_{3} \mathrm{O}_{4}\right)^{4}$ になっている可能性がある. $\mathrm{Fe}_{3} \mathrm{O}_{4}$ の平均結晶子の大きさはボイラ及びフィルタでそれ ぞれ 105, $27 \mathrm{~nm}$ である。，一方， $\alpha-\mathrm{Fe}_{2} \mathrm{O}_{3}$ の場合，格子 定数はボイラ、フィルタのいずれもバルクに一致し ている．平均結晶子の大きさはボイラ及びフィル夕 でそれぞれ 161，24 nm である.このように $\mathrm{Fe}_{3} \mathrm{O}_{4}$. $\alpha-\mathrm{Fe}_{2} \mathrm{O}_{3}$ の平均結晶子の大きさがいずれもボイラとフ ィルタで差が生じているのは，生成条件として両者 の間で $100^{\circ} \mathrm{C}$ の温度差があるためと考えられる.

\section{$3 \cdot 2$ 電子顕微鏡観察}

ボイラとフィルタからの磁着物について TEM 観察 を行った結果を、Photo. 1・(1)，及び(2)に示した，粒 子形態はいずれも粒状と考えられる. Photo. 1・(1) で†A， Bで示す粒子は $\mathrm{Fe}_{3} \mathrm{O}_{4}$ と考えられ，それらの 粒度は 100 200 nm で，前述した X 線回折から求めた 結晶子の大きさにほぼ一致している. Photo. 1·(2) の中で $\uparrow B$ で示した粒子は約 $200 \mathrm{~nm}$ であって，X線回 折により求めた結晶子の大きさ， $27 \mathrm{~nm}$ とは一致しな

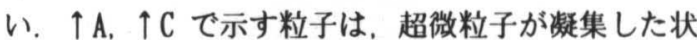
態と考えられ，X線的な結晶子の大きさと対応してい るものと思われる。

次に，Photo. 1・(1)，及び(2)の中で， (9)印は a, b, c などと図示した約 $20 \mathrm{~nm}$ 径の微小領域である。これ

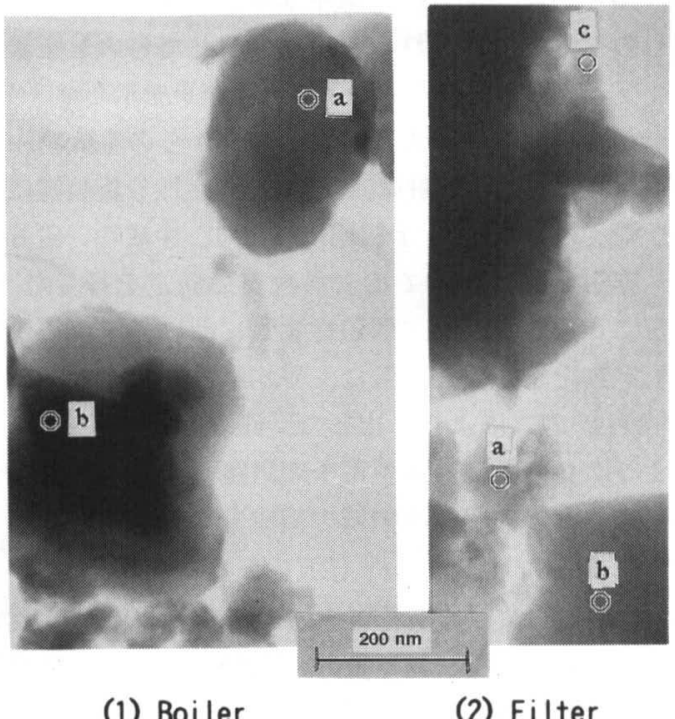

(1) Boiler

(2) Filter

Photo.1 Photograph of substances taken by TEM. 
らは，EDXによりこの領域について組成分析を行った ことを示している，それらの特性 X 線スペクトルを Photo. 1·(1)の@a, Obに対応してFig. 4 (1). (2) に. Photo. 1 - (2)の○a, Ob, ○cに対応してFig. 5 (1)（2)，(3)に示した，いずれのスペクトルも組成

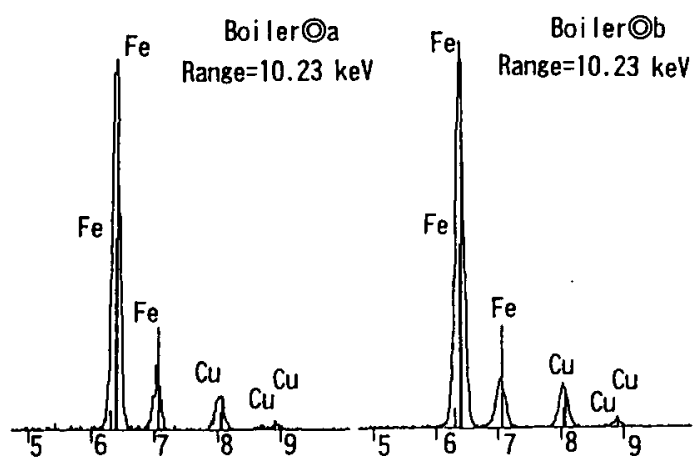

(1) BoilerOa

(2) Boiler@b

Fig.4 Element analysis by EDX.

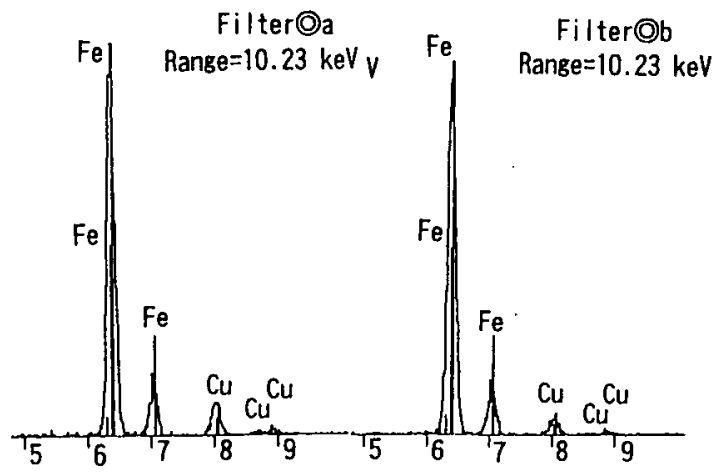

(1) Filter@a

(2) Filter@b

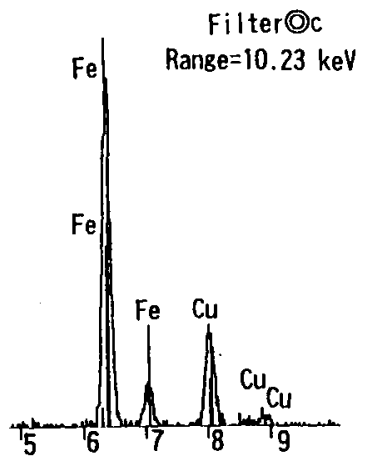

(3) FilterOc

Fig.5 Element analysis by EDX.
としてはFeが主で，これにある程度のCuが含まれて いる. 特に.Fig. 5 (3)ではCuが多く含まれている. これらの值を半定量的に求めたものが Table 3である. ボイラからの Fig. 4 (1)，(2)及び Fig. 5 (1)，(2) の領域中のCuの含有量は約 10 at\%前後である.これ に対して Fig. 5 (3)は 25 at\%も含まれている. EDX は超微小領域からの組成情報であり，必ずしも全体 情報とは一致しないが、Photo.1・(2)中には@cのよ うな $\mathrm{Cu}$ 含有量の多い粒子が数多く含まれていて，そ のため Table 1 の栄光 X 線定性分析で $\mathrm{Cu}$ 含有量が多 く示されているのかも知れない.

Table 3 Analysis of magnetic substances formed in microscopic area by EDX.

\begin{tabular}{|l|c|c|c|c|}
\hline & \multicolumn{2}{|c|}{ Weight\% } & \multicolumn{2}{c|}{ Atomic\% } \\
\cline { 2 - 5 } & Fe-k a & Cu-k a & Fe-k a & Cu-k a \\
\hline Boiler@a & 86 & 14 & 88 & 12 \\
\hline Boiler@b & 87 & 13 & 88 & 12 \\
\hline Filter@a & 89 & 11 & 90 & 10 \\
\hline Filter@b & 94 & 6 & 94 & 6 \\
\hline Filter@c & 73 & 27 & 75 & 25 \\
\hline
\end{tabular}

$3 \cdot 3$ 磁気的性質

$3 \cdot 3 \cdot 1$ 磁化湘定

ボイラとフィル夕について，300K で磁化 $\sigma$ の測定 を行い，結果をFig. 6 に示した，磁着物の磁化曲線 はヒステリシスを描き，約 $10 \mathrm{k} 0 \mathrm{e}$ 以上の磁界ではほ ぼ飽和する傾向を示している，また，生成物及び非 磁着物も磁着物に比べ磁化は小さいが，ヒステリシ スを示している。これはある程度の含有比で存在す る强磁性殿粒子によるものと考えられる。

$3 \cdot 3 \cdot 2$ 磁気的不活性層補正後の磁化

ボイラとフィルタからの磁着物の平均粒度は，す でに述べたように，それぞれ105，27n⿴である，また。 それぞれの磁化の值は $79.78 \mathrm{emu} / \mathrm{g}$ である。.これら 磁着物中における強磁性微粒子が内部のコア部分 （磁気的活性部分）と表面層部（磁気的不活性部分） に分かれていると仮定すると，磁気的不活性層の存 在は強磁性微粒子の磁化の値を下げることになり，7 したがって，実測值は粒子内のコアの部分のみが等 与していると考えられる。位粒子表面には $0.8 \mathrm{~nm}$ の磁気的不活性層が存在するとし， " 粒度に対応した 形で，コア部分の粒子全体に対する体積比を求めて みると，それぞれ0.96、0.83 となる。これらの值を 用いて，粒子表面の非磁性部分を補正し，粒子全体 がコア部分と同じ磁化を示すものとして，磁化の值 
を求めると：ボイラとフィルタではそれぞれ 82,93 $\mathrm{emu} / \mathrm{g}$ と大さな值になる. バルクの $\mathrm{Fe}_{3} \mathrm{O}_{4}$ 及び $\gamma-\mathrm{Fe}_{2} \mathrm{O}_{3}$ の $300 \mathrm{~K}$ での $\sigma_{s}$ の值はそれぞれ $92,78 \mathrm{emu} / \mathrm{g}$

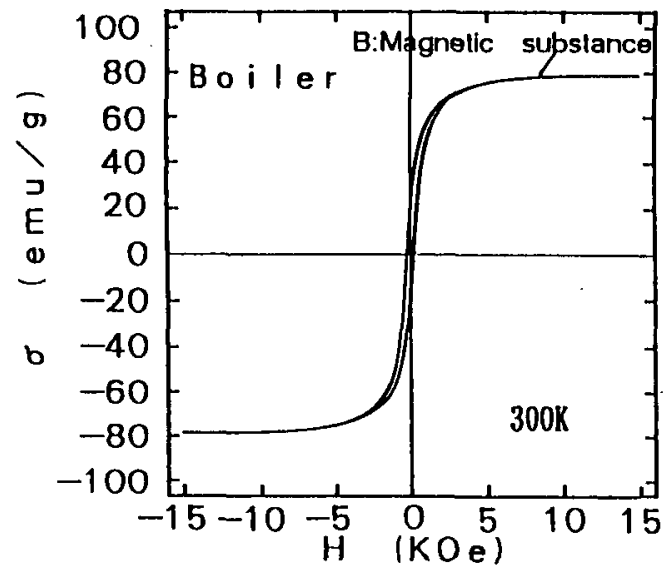

Fig.6 Magnetization curve of the substance.

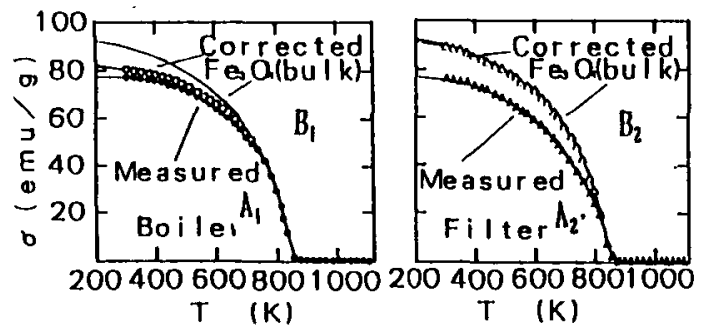

Fig.7 Temperature dependence of magnetization.

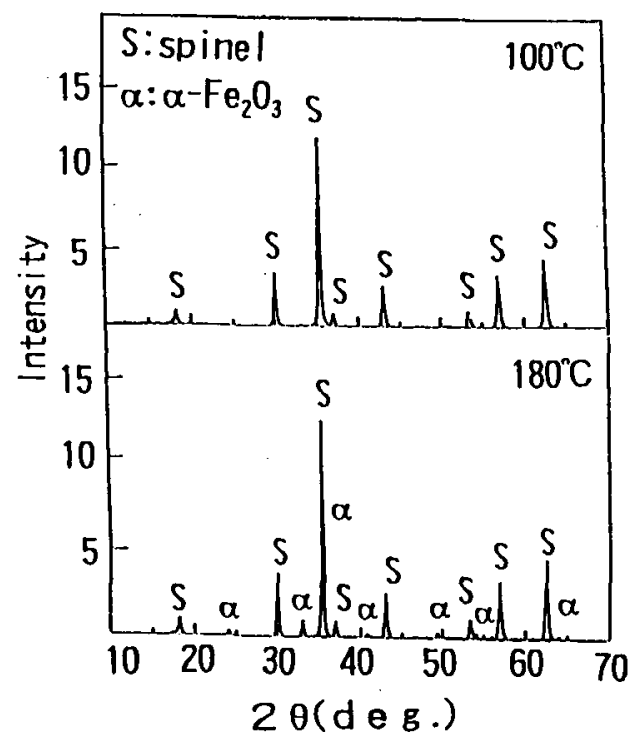

Fig. 8 X-ray difraction paterns of typical samples formed using Autoclave.
であるので，これら強磁性微粒子の磁化はバルクの $\mathrm{Fe}_{3} \mathrm{O}_{4}$ にかなり近い值となっている.

さらに，ボイラ及びフィルタからの磁着物につい て. 300〜1100K の範囲で熱磁化曲線を示したのが Fig.7である. 図中， $A_{1} 、 A_{2}$ はボイラ及びフィルタそ れぞれの碚着物についての実測値を示したものであ る. 同様に $B_{1} 、 B_{2}$ は $A_{1} ， A_{2}$ それぞれについて粒子表面 の磁気的不活性層を補正した後の值である．磁着物 のキュリー点はいずれも約 $850 \mathrm{~K}$ を示し、バルクの $\mathrm{Fe}_{3} \mathrm{O}_{4}$ の值 $860 \mathrm{~K}$ とほぼ一致している.

Table 4 Composition of cast iron for boiler.

\begin{tabular}{|c|c|c|c|}
\hline T.C & $\mathrm{Si}$ & $\mathrm{Mn}$ & $\mathrm{P}$ \\
\hline 3.57 & 2.10 & 0.64 & 0.07 \\
\hline \multicolumn{4}{|c|}{ T.C:Total Carbon }
\end{tabular}

Table 5 Magnetization of the samples formed using Autoclave.

\begin{tabular}{|c|c|c|}
\hline $\begin{array}{c}\text { Reaction } \\
\text { temperature } \\
\left({ }^{\circ} \mathrm{C}\right)\end{array}$ & $\mathrm{p} \mathrm{H}$ & $\begin{array}{c}\text { Magnetization } \\
\text { (emu/g) }\end{array}$ \\
\hline 80 & 10.25 & 83.96 \\
\hline 100 & 10.22 & 85.55 \\
\hline 120 & 10.06 & 85.11 \\
\hline 140 & 10.30 & 84.25 \\
\hline 160 & 10.11 & 82.38 \\
\hline 180 & 10.16 & 79.64 \\
\hline
\end{tabular}

\section{3・4 鉄系生成物の生成過程}

鉄系生成物中には， $\mathrm{Fe}_{3} \mathrm{O}_{4}$ と $\alpha-\mathrm{Fe}_{2} \mathrm{O}_{3}$ が含まれている が、これらの生成過程について検討を行った。 まず， 蒸気発生源である市水中の $\mathrm{Fe}$ 含有量はごく僅かであ る4．一方，Table 4 のボイラの化学成分表を見ると， $\mathrm{Fe}$ は他の成分に比べてかなり多い. したがって，ボ イラを運転していると，ボイラ及び配管は少しずつ 腐食して Fe を主とする金属が水溶液中に容けだし， $\mathrm{Fe}_{3} \mathrm{O}_{4} や \alpha-\mathrm{Fe}_{2} \mathrm{O}_{3}$ が生成する主要因となるものと考えら れる，ボイラ及び配管の金属 (Fe) が水溶液中で電気 化学反応により腐食される過程は以下の反応による ものと考えられる.

ボイラ及び配管水溶液の $\mathrm{pH}$ は稼倒時から $\mathrm{NaOH}$ 等に より 10.5〜11.0に維持され,アルカリ性水となり $\mathrm{OH}^{-}$ が水溶液中に存在する．また，アノード反応により 循䍗する水溶液中に少しずつ溶け出した Fe は水酸化 鉄 (II) $\left[\mathrm{Fe}(\mathrm{OH})_{2}\right]$ として生成沈殿する.この $\mathrm{Fe}(\mathrm{OH})_{2}$ が水溶液中の溶存酸素によってある程度酸化されて 水酸化鉄 (III) $\left[\mathrm{Fe}(\mathrm{OH})_{3}\right]$ となり，この両水酸化鉄間 の反応で $\mathrm{Fe}_{3} \mathrm{O}_{4}$ が生成すると考えられる．この場合。 温度，pH，酸化速度等の生成条件が重要となる ${ }^{8)}$ 。こ 


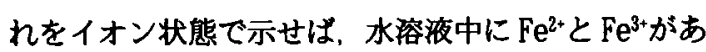

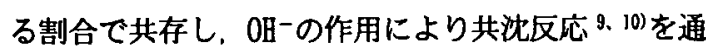
じて $\mathrm{Fe}_{3} \mathrm{O}_{4}$ が生成されるものと考えられる。な の生成反応には $3 \mathrm{Fe}(\mathrm{OH})_{2} \rightarrow \mathrm{Fe}_{3} \mathrm{O}_{4}+\mathrm{H}_{2}+2 \mathrm{H}_{2} \mathrm{O}$ で示される シッコール反応 ${ }^{3) か ゙ あ る か ゙ 、 こ れ は ~} 200^{\circ} \mathrm{C}$ 以上の高温 中の反応条件で起こるものである.

次に，これまで述べたように蒸気発生温度が高く なると、 $\mathrm{Fe}_{3} \mathrm{O}_{4}$ の他に $\alpha-\mathrm{Fe}_{2} \mathrm{O}_{3}$ が含まれてくる.オート クレーブを用いて試行実験を行った。試薬は

$\mathrm{FeCl}_{2} \cdot 4 \mathrm{H}_{2} \mathrm{O}$ [塩化鉄（II） 4 水和物] で. 生成条件と して $\mathrm{NaOH}$ を用い $\mathrm{pH} 10$ で反応温度 $\left[80 \sim 180^{\circ} \mathrm{C}\left(20^{\circ} \mathrm{C}\right.\right.$ 毎) ], 反応時間 (5 時間)，また，溶液濃度は $5000 \mathrm{ppm}$ とした，得られた試料の測定結果を Table 5に示した. 反応温度が $140^{\circ} \mathrm{C}$ 以上になると，磁化の值が減少して いる.これは Fig. 8 の X線回折線結果からも知られ るように $\mathrm{Fe}_{3} \mathrm{O}_{4}$ の他に $\alpha-\mathrm{Fe}_{2} \mathrm{O}_{3}$ が生成してくるためと 考えられる.この試行実験結果を実際のボイラの条 件にあてはめて検討してみる。100年の暖房用ボイラ の場合には鉄系生成物の中に $\alpha-\mathrm{Fe}_{2} \mathrm{O}_{3}$ は含まれない.4 しかし、 $180^{\circ} \mathrm{C}$ 高温蒸気供給用ボイラの場合は，反 応時間が実際のボイラの稼働時間に比べて短いが， $\alpha-\mathrm{Fe}_{2} \mathrm{O}_{3}$ が含まれている.これらのことから，温度が 上昇すると，鉄系生成物の中に $\alpha-\mathrm{Fe}_{2} \mathrm{O}_{3}$ が生成するお およその傾向を知ることができた．なお， $\alpha-\mathrm{Fe} 00 \mathrm{H}$ が 生成している可能性も考えられる，さらに，Table 1 によると、フィルタでは Cu0 が約 10\%も含まれてい る.これは熱交換機の銅パイプの腐食によるもので ある、また，Zn0が約 1\%含まれているが，これは $\mathrm{Zn}$ メッキ配管から $\mathrm{Zn}$ が容け出したことにより生成した ものと考えられる.

\section{4 結 言}

ボイラ及びフィルタから生成する鉄系生成物に重 点を置いて行った研究結果を要約すると次の通りで ある。

1）蛍光 X 線定性分析により生成物の成分元素を測 定したところ，鉄酸化物が約 $98 \%$ も含有されること が分かった。

2） X 線回折により格子定数を測定した結果，磁着物 は $\mathrm{Fe}_{3} \mathrm{O}_{4}$ に，非磁着物は $\alpha-\mathrm{Fe}_{2} \mathrm{O}_{3}$ に一致することが分 かった．また，ボイラ及びフィルタからの $\mathrm{Fe}_{3} \mathrm{O}_{4}$ の粒 度はそれぞれ 105，27nnであり，一方、ボイラからの $\alpha-\mathrm{Fe}_{2} \mathrm{O}_{3}$ は $160 \mathrm{~nm}$ であった。

3）TEM 観察によると，磁着物の粒子形態は粒状であ る.これから求めた粒度は $\mathrm{X}$ 線的に求めた結晶子の
大きさと一致していると考えられる．また，EDXによ る組成分析結果は，磁着物の主成分は Fe であること が分かったささらにフィルタの場合，Cu0 含有量の多 い粒子が存在することが分かった。

4）磁着物の，磁化の実測値は $78 \sim 79 \mathrm{emu} / \mathrm{g}$ と大き な値を示すが，粒子表面の非磁性層部分の補正を行 うと，磁化の值は 82 93 emu/g とさらに大きくなり. バルクの $\mathrm{Fe}_{3} \mathrm{O}_{4}$ に近い值であることがわかった. また， キュリー点は $850 \mathrm{~K}$ を示し, バルクの $\mathrm{Fe}_{3} \mathrm{O}_{4}$ の $860 \mathrm{~K}$ と ほぼ一致している。

5）鉄系生成物の生成過程としては，ボイラ及び配管 から少しずつ腐食して Fe が溶出し，カソード反応と アノード反応を通じて $\mathrm{Fe}(\mathrm{OH})_{2}$ となり，酸化一共沈反 応を通じて最終的に $\mathrm{Fe}_{3} \mathrm{O}_{4}$ と $\alpha-\mathrm{Fe}_{2} \mathrm{O}_{3}$ として生成する ものと考えられる.

\section{謝 辞}

本研究を行うに当り，ボイラ内生成物の TEM 観察. X線回折，生成物の採集等で御協力頂いた NTTアドバ ンステクノロジ取締役の石本明輝氏，材料分析セン 夕所長の服部誠示氏，材料分析担当部長の関 昌浩 氏、昭和熱化学工業社長の宮川澄男氏に深く感謝致 します，また、オートグレーブの試行実験、データ 整理等で協力してくださった本学院生の中村昭彦君, 卒研生の越智武規君，植野浩征君に感謝する次第で ある.

\section{文 献}

1) 水野孝之, 和田邦彦，岩堀 徽：電気化学, 46, (1973) 494.

2)若原高生，河合重好，前川政次，永久博司，大河 原浩: 火力原子力発電, 44.（1993） 34 .

3)汽力発電所給水処理ハンドブック, 電力中研, (1985).

4)石橋新一郎，佐藤寿彦，羽田紘一，関昌浩: 粉体 および粉末治金、42.（1995）47.

5)平賀貞太郎，奥谷克伸、尾島輝彦: フェライト，丸 善, (1988) 166.

6) 太田恵造: 磁気工学の基礎 I，共立出版，(1980）.

7)T. Sato, T. I ijima, M. Seki and N. Inagaki : J. Magn. Magn. Mat., (1987).

8) 木山雅雄：粉体および粉末治金，23，（1976）77.

9）下飯坂潤三：日本金属学会会報, 15、(1976）77.

10)T. Sato, C. Kuroda and M. Sai to : Pro. Intern. Conf. Ferrites, (1971) 72. 